\title{
JAKOBSHAVNS ISBRE, WEST GREENLAND: SEASONAL VARIATIONS IN VELOCITY - OR LACK THEREOF
}

\author{
By Keith EChELMEyer and William D. Harrison
}

(Geophysical Institute, University of Alaska-Fairbanks, Fairbanks, Alaska 99775-0800, U.S.A.)

\begin{abstract}
The lower $80 \mathrm{~km}$ of the fast-moving Jakobshavns Isbræ, West Greenland, is subject to significant melting during the summer season. The melt water drains into large supraglacial rivers which pour into moulins or feed into beautiful supraglacial lakes, some of which are observed to drain periodically. Except for a few streams that drain directly off the margins of the ice sheet within the drainage basin of this glacier, the fate of this melt water is unknown. However, a localized upwelling of highly turbid water is often observed during the melt season in the fjord adjacent to the terminal cliff of the glacier, indicating that water from some source does move along the glacier bed.

As part of an investigation on the mechanisms of rapid flow on Jakobshavns Isbræ, measurements of surface velocity at several $(\sim 25)$ locations along the ice stream at and below the equilibrium line were made in order to investigate the effects of this seasonally varying input of melt water on the speed of the glacier.

No significant seasonal variation in speed was found at any location. This indicates that, unlike many other sub-polar and temperate glaciers, surface melt-water production does not affect the motion of this glacier on a seasonal basis, and, thus, does not cause a significant temporal variation in basal sliding. This finding has important ramifications on the mechanisms of flow for this ice stream.
\end{abstract}

\section{INTRODUCTION}

Glaciers of ten show seasonal variations in surface speed. The fluctuations are often attributed to changes in the amount of basal sliding and/or deformation of a basal debris layer. This increase or decrease in basal motion is related to changes in the basal hydraulic system, with higher subglacial water pressure in the early summer giving rise to an effective increase in basal "lubrication".

Observations of the seasonal variation in velocity of glaciers are many. Some temperate glaciers exhibit a sharp increase in speed during the early part of the ablation season, with the "DC" shift in speed being in the range of $20-100 \%$ of the wintertime speed. Several recent references include Hodge (1974; Nisqually Glacier, Washington), Iken (1978, 1981; Findelengletscher and Unteraargletscher, Switzerland); Hooke and others (1983; Storglaciären, Sweden), Raymond and Harrison (1988; Variegated Glacier, Alaska), and Harrison and others (1989; Fels and Black Rapids Glaciers, Alaska).

Theoretical and observational evidence (see, for example, Lliboutry, 1968; Weertman, 1979; Iken, 1981; and Boulton and Vivian, 1973; Iken and others, 1983; Iken and Bindschadler, 1986; Kamb and Engelhardt, 1987, respectively) predicts and shows (respectively) a direct correlation between the subglacial water pressure (which decreases the effective normal stress) and the rate of basal motion. The difference in velocity between the mean winter value and that measured in the early melt season at a given spatial location is of ten interpreted as an increase in basal motion (e.g. see discussion by Raymond and Harrison, 1988, and Hooke and others, 1983), and this increase is a direct consequence of increased melt-water flux to the basal hydraulic system.

Seasonal velocity variations have also been observed on some sub-polar (Arctic)-type glaciers, such as on glaciers in Greenland (Battle, 1951; Paterson, 1961; Andreasen, 1985) and White Glacier, Arctic Canada (Iken, 1974). Iken (1974) has measured variations in the water level in moulins on White Glacier (which can be interpreted as changes in basal water pressure), and these are correlated with the velocity fluctuations. Thus, it appears that surface melt water can penetrate to the bed and influence basal motion even when the ice is cold at the surface.

Not all glaciers show such a seasonal acceleration. For example, the temperate Blue Glacier, Washington, shows very little increase in speed $(<5-10 \%)$ during the onset of the melt season (Echelmeyer, unpublished). Engelhardt and others (1978) found very low or zero sliding rates at the base of this glacier during the summer. The motion of this glacier thus appears to be almost entirely due to internal deformation, even though there is a large influx of surficial melt water to the glacier system in the summer and many moulins are present to transport this water into the glacier. The melt water does emanate from basal streams at the terminus, and is highly charged with glacial flour.

With these concepts in mind, seasonal velocity and summer ablation measurements were performed as a part of the 1984-86 field program on Jakobshavns Isbræ in West Greenland. This outlet glacier/ice-stream system moves at an extremely high speed, and it is similar in some respects to the ice streams of West Antarctica. The mechanisms by which this glacier attains such high speeds are unknown, and it was postulated that useful insight into these mechanisms could be achieved by seasonal measurements. A discussion of these measurements forms the basis of the present paper.

The seasonal velocity measurements are discussed first. Next is a discussion of the rate of surficial melt-water production and its transport, and this is followed by an estimation of the water production at the base of the ice. The implications of the observed velocity variations and the possible sources of basal water input are then discussed in the context of the mechanisms for rapid flow.

A detailed description of the location, morphology, and surficial glaciology of the Jakobshavns Isbræ system is given in a companion paper by Echelmeyer and Harrison (paper in preparation; denoted here as $\mathrm{E}$ and $\mathrm{H}$ ).

One point worth noting here is that the extreme surface velocities $\left(>200 \mathrm{~m} \mathrm{a}^{-1}\right)$ extend inland to a location which is approximately $50 \mathrm{~km}$ inland from the limit of seasonal ablation. Further inland of this point the velocity decays to more ice-sheet-like values $\left(\leqslant 100 \mathrm{~m} \mathrm{a}^{-1}\right)$. This location is nearly $200 \mathrm{~km}$ closer to the margin than the point at which numerical simulations predict a change from a frozen to a melting basal regime (see, for instance, Budd and others, 1982, map 6/2; Radok and others, 1982, fig. 5.18). Therefore, those locations where the bed may be at the melting point include, but are not limited to, the regions of extremely high surface velocities. 
METHODS AND ERRORS IN VELOCITY MEASUREMENTS

Several markers were emplaced in the surface of the glacier over the period August 1984-October 1986 (E and $\mathrm{H})$. Of these markers, approximately 25 were surveyed at various times of the year so as to obtain representative seasonal velocities. The location of the different markers is shown in Figures 1 and 2.

A few of the markers (A3, A6, M4, M5, N2, and N3) could be surveyed from the survey site ANNE on the northern fjord margin. Terrestrial surveying techniques were used (EDM and theodolite), with an estimated error in horizontal position of about $0.1-0.3 \mathrm{~m}$ (depending on the shot distances and the presence or lack of a fixed retroreflecting prism at the marker).

Two methods were used to position the remaining markers, whose distance from land or visibility problems made visual methods unfeasible. One method involved the use of two satellite doppler geoceivers, one of which was in continuous operation at a fixed base station (ANNE) (or, in some cases, there were two fixed stations). The other

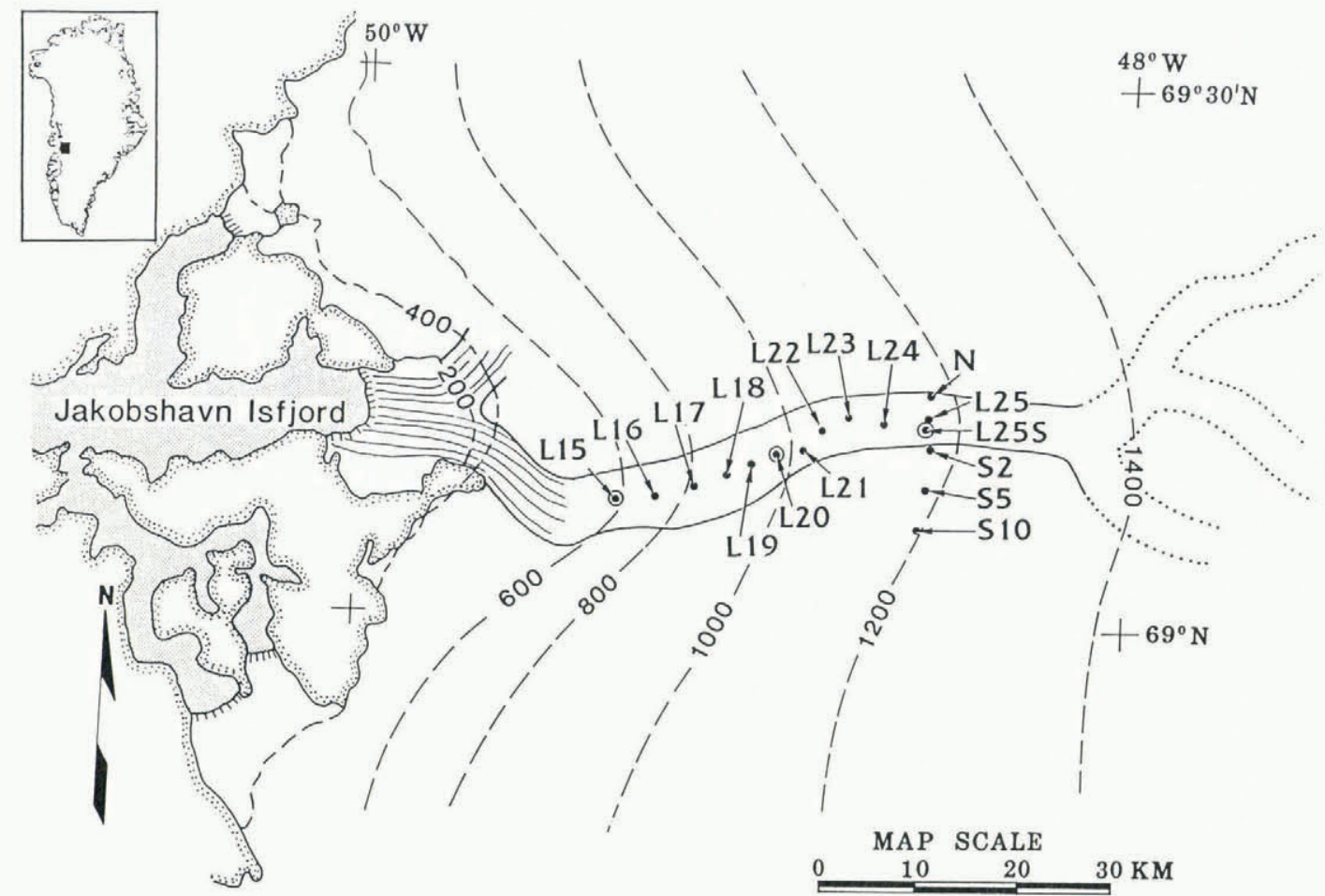

Fig. 1. Map of Jakobshavns Ice Stream, showing location of markers above the grounding zone. Elevation contours follow those of $H$. Brecher and $T$. Hughes (personal communication). The grounding zone is located between the 200 and $400 \mathrm{~m}$ contours.

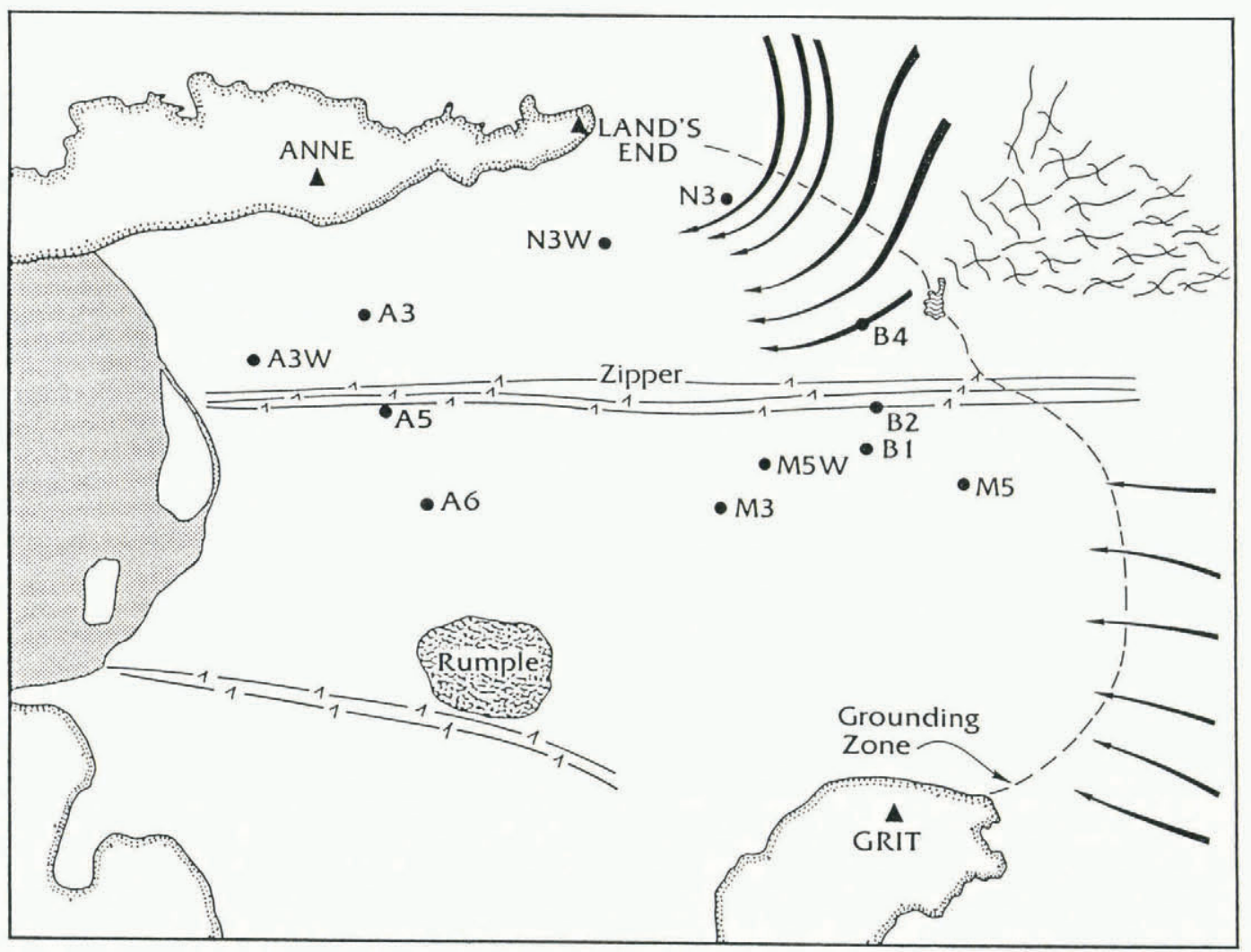

Fig. 2. Map of the lower. floating region of Jakobshavns Isbra showing location of markers below grounding zone. 
geoceiver was placed at a given marker on the ice for approximately $24 \mathrm{~h}$ (long enough to track about 30 satellite passes). The data from both geoceivers were then reduced simultaneously to yield accurate coordinates (latitude, longitude, elevation) using translocation methods (personal communication from $\mathrm{H}$. Brecher). The coordinates determined using these geoceivers have an estimated error of $0.5 \mathrm{~m}$. The second method involved the use of a UHF positioning system. Fixed remote transceivers were placed at two sites of known position on bedrock (location determined by satellite positioning), separated by a distance of approximately $45 \mathrm{~km}$ along a line normal to the ice stream through the base camp. A master transceiver was mounted on a helicopter and linked to a portable computer for data acquisition. Ranges from the two fixed remotes were obtained while the antenna of the master unit was placed directly on the various markers using a hovering helicopter This method is believed to have a position accuracy of approximately $2 \mathrm{~m}$ for the geometry and distances involved when base-line calibration could be performed, and $4 \mathrm{~m}$ when conditions did not allow calibration. Calibration was performed by hovering the antenna over a fixed mark at the base camp.

As markers were not reset to fixed spatial positions, the velocities obtained from these various position measurements represent an estimate of the velocity for a moving parcel of ice in the Eulerian sense. We are interested in the surface velocity at a fixed position in space, however, and therefore must correct for the non-zero change in velocity as the marker moves along its flow line. The distribution of the longitudinal gradient in velocity has been used to reduce the horizontal velocities obtained at different times for a given marker to a fixed point in space. (This assumes that the longitudinal velocity gradient is uniform in time, which, as we shall see below, is a reasonable assumption). This correction for longitudinal gradients in velocity is perhaps the greatest source of error in the values of velocity described below. This is because the local gradients can be large (generally $0.1-0.2 \mathrm{a}^{-1}$ but ranging up to $1.4 \mathrm{a}^{-1}$ near the grounding zone; see $\mathrm{E}$ and $\mathrm{H})$ and they could be coupled with any seasonal variation which might be present. The gradients used to correct the Eulerian velocities to the winter positions were obtained either by comparison of 1984-85 and 1985-86 mean velocities as a marker moved a known distance along the flow line or from the gradient between simultaneous velocity measurements at two markers placed a few (2-5) kilometers apart along the ice stream (generally, but not always, along a flow line).

\section{OBSERVED VELOCITIES}

Horizontal velocity measurements have been grouped into the following three seasonal intervals:

(1) Dead of winter: as obtained from measurements made over the period 26 February-12 March 1986 on the lower glacier, or 26 February-26 May 1986 at locations above the grounding zone and at some locations below it.

(2) Spring: approximately 25 May-21 June 1985 or 26 May-26 June 1986 - the time periods when significant surface melting started below $1200 \mathrm{~m}$ and when saturation of the snow-pack was occurring at these elevations.

(3) Summer/fall: above the grounding zone, approximately 26 June-4 October 1986 including the period of peak melt and the end of the ablation season (early September), or 21 June-early August 1985 at some locations below the grounding zone.

Estimated probable errors in velocity for markers surveyed using non-terrestrial methods (those above the grounding zone and B1, B2) are about $15 \mathrm{~m} \mathrm{a}^{-1}$ in the winter, $30 \mathrm{~m} \mathrm{a}^{-1}$ in spring, and $12 \mathrm{~m} \mathrm{a}^{-1}$ in summer/fall. These errors in winter, spring, and summer/fall (which include velocity gradient-correction errors) represent, respectively, about $0.5-3,1-6$, and $0.4-2.5 \%$ of the actual horizontal velocity at a given location. Nearly simultaneous measurements of velocity at a given location using electronic positioning and satellite methods show a maximum difference of about $2 \%$ between the two methods, consistent with the above error estimates.
For those markers surveyed by terrestrial means, the errors in velocity are dominated by longitudinal velocity gradient-correction errors. Near the calving terminus, these errors can vary in time since a large calving event can place a given marker several kilometers closer to the newly formed calving face in less than an hour, and velocity gradients can be large there (see $\mathrm{E}$ and $\mathrm{H}$ ). With an error of $0.05-0.1 \mathrm{a}^{-1}$ in the longitudinal velocity gradient and the high absolute velocities observed in the floating region $\left(2000-7000 \mathrm{~m} \mathrm{a}^{-1}\right)$, an error of $60-150 \mathrm{~m} \mathrm{a}^{-1}$ is possible. This represents a relative error of about $2-3 \%$, similar to that found above.

Horizontal surface velocities obtained over the above time periods (i.e. the local time rate of change in position of a point on the surface as viewed at a fixed location in space) are shown in Figures 3 and 4 . The striking feature

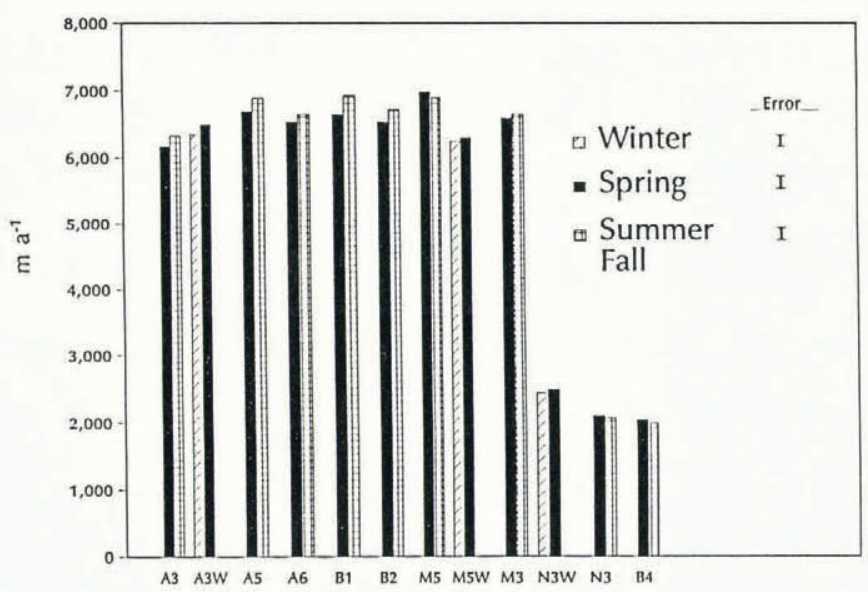

Fig. 3. Seasonal velocities at positions below grounding zone. Location of these markers is shown in Figure 2. Maximal error bars are shown.

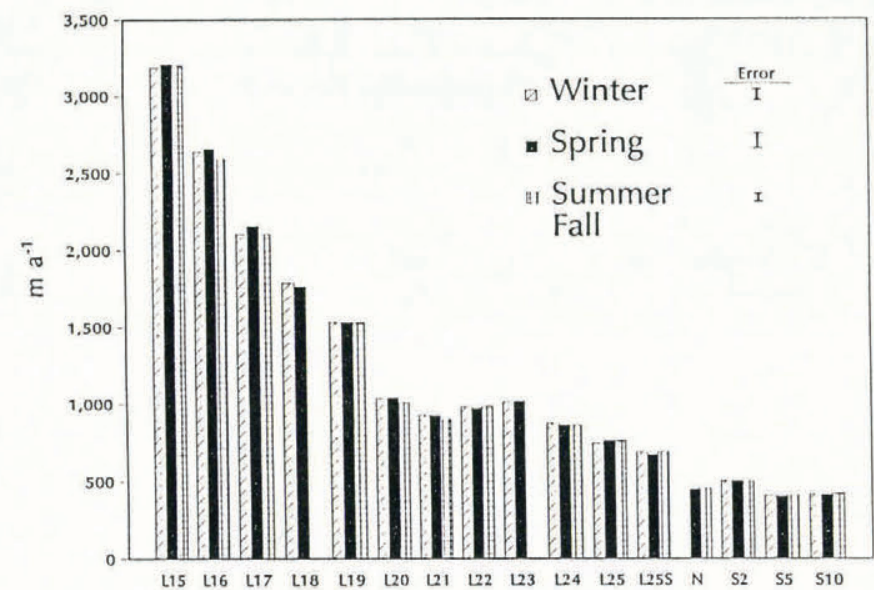

Fig. 4. Seasonal velocity at positions along ice stream above grounding zone. Maximal error bars are shown.

of these diagrams is the complete absence of any significant variation in velocity at a given location throughout the year. Most fluctuations in speed are small in comparison to the absolute velocity and, generally, are smaller than the probable errors in the velocity ( $<3 \%$ of the mean velocity). At some locations on the lower, floating glacier, the difference between seasonal velocities approaches $4 \%$ (e.g. B1), but time-varying longitudinal gradients and errors in these gradients could contribute to these different speeds. In any case, seasonal variations in speed are less than $3-4 \%$ of the mean annual speed at all locations.

It is interesting to note that the velocity of the lower glacier does vary substantially (by as much as $35 \%$ ) over short time periods (e.g. tidal frequencies). This is discussed 
by Echelmeyer and Harrison (paper in preparation). Such a short-period variation possibly leads to some error in the mean seasonal velocities shown in Figure 3 for the shorter time periods (such as 2 weeks in winter).

\section{MELT-WATER PRODUCTION AT THE SURFACE}

Beginning in late May and continuing to mid-August, there is significant melting at elevations below about $1200 \mathrm{~m}$. Complete saturation of the thin snow-pack occurred in the month of June during 1985 and 1986 below this elevation. Ablation rates, as determined during the mass-balance studies described in $E$ and $H$, reached a peak in mid-July. Below about $1100 \mathrm{~m}$, the melt water forms extensive supraglacial stream networks, centered in the concave surface profile of the ice stream. Some of the major trunk streams reach major proportions. There are several smaller streams that drain directly off the ice sheet on to the land. From about 1100 to $1200 \mathrm{~m}$ extensive slush swamps form. Large supraglacial lakes form at all elevations below $1200 \mathrm{~m}$ and crevasses are of ten partially filled with water in many areas within the ice stream itself. Some of the lakes have been observed to drain annually, while others remain at least partially filled from year to year. Certain lakes are advected down-glacier with the years, while others are observed to form at fixed spatial locations, such as below the ice-fall region in the grounding zone.

There is a large stream along the center of the glacier above about $900 \mathrm{~m}$, below which crevassing becomes too prevalent to allow river formation. The stream terminates abruptly at this elevation, where it plunges into a gigantic moulin. The river at this point is approximately $10 \mathrm{~m}$ wide and $2 \mathrm{~m}$ deep, with a discharge of about $50-80 \mathrm{~m}^{3} / \mathrm{s}$. An attempt to lower a pressure transducer into this moulin was made during July of 1985 . About $500 \mathrm{~m}$ of cable was lowered into the moulin, but no indication of a standing water level was obtained. Either the transducer had become lodged higher in the moulin or englacial-subglacial water pressure heads were beneath this level.

During the melt season, melt-water input to the glacier system occurs over an area of nearly $3000 \mathrm{~km}^{2}$. The observed ablation rate (in water equivalent) versus elevation along the ice-stream center line is shown in Figure 5. Measurements made along Jakobshavns Isbræ during July

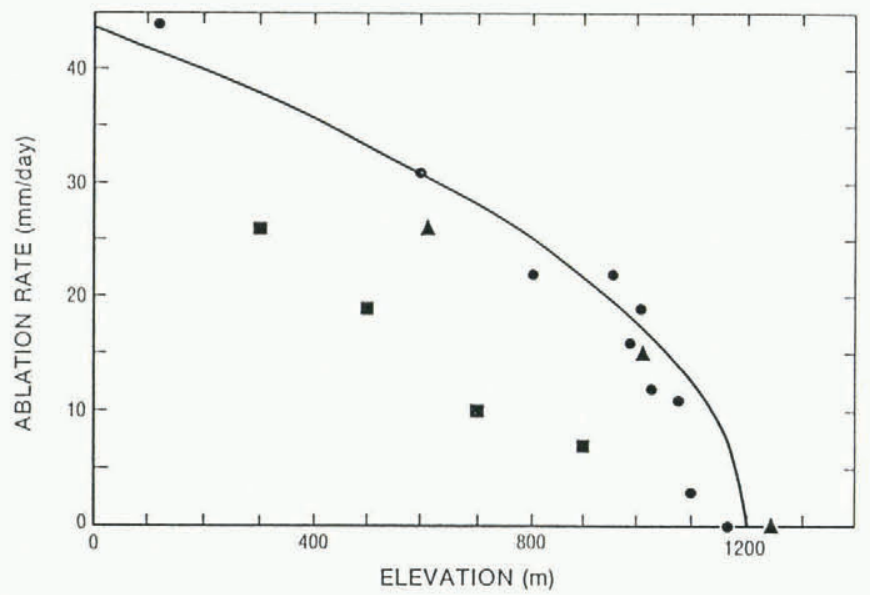

Fig. 5. Ablation rate in water equivalent $(\mathrm{mm} / \mathrm{d})$ as a function of elevation. Curve is empirical relation given by Equation (1). Squares are data from Thomsen (1984). triangles from Ambach (1977), and circles from $E$ and $H$.

and early August 1984 to 1988 agree well with those obtained by Ambach (1977) along the EGIG line $60 \mathrm{~km}$ to the north. However, the observed ablation rates are significantly greater than those measured by Thomsen (1984) during the summer of 1983 at a location $45-60 \mathrm{~km}$ to the north. The year of his measurements (1983) may have been cooler and/or the measurement period of Thomsen (early June-mid-August) may have included periods of low melt at the beginning and end of the ablation season, which would affect the overall ablation rates.

An empirical relationship for the measured rate of melting, $a(\mathrm{~mm} / \mathrm{d})$, per unit area as a function of elevation, $z(\mathrm{~m})$, is given by:

$$
a(z)=1.26(1200-z)^{\frac{1}{2}} .
$$

The width of the lower drainage basin, as obtained from an air-photo map compiled by $\mathrm{H}$. Brecher and T. Hughes (personal communication), is shown in Figure 6. The width in meters, $w$, can be represented in the empirical form:

$$
w(z)=81.4 z-330
$$

up to an elevation of $1200 \mathrm{~m}$. An estimate of the total

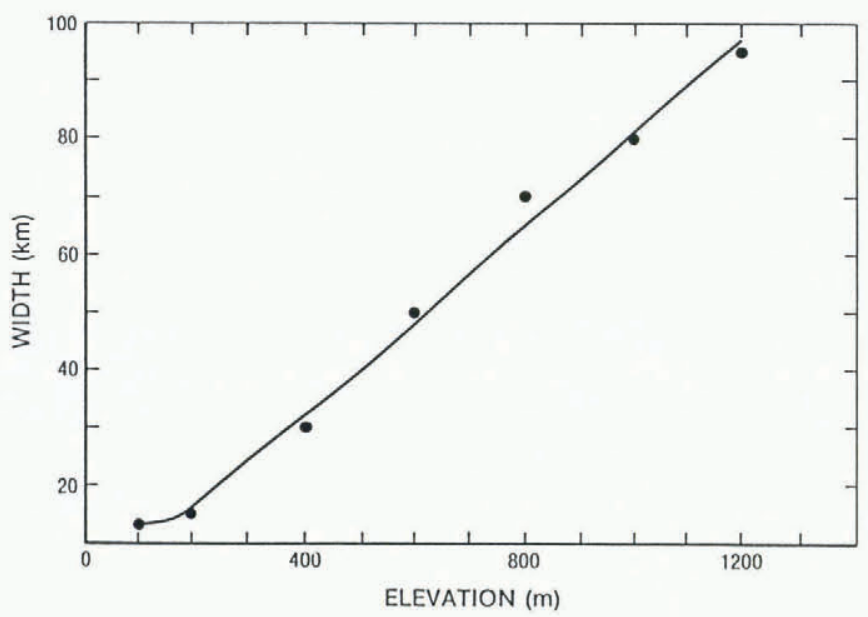

Fig. 6. Width of drainage basin with elevation. Best-fit linear relation is given by Equation (2).

input rate of surficial melt water to the system, $Q_{S}$, during the height of the ablation season can be obtained from the relation

$$
Q_{\mathrm{S}}=\int_{z_{0}}^{z_{1}}[a(\zeta) w(\zeta) / \sin \theta] \mathrm{d} \zeta
$$

where we take $z_{0}=200 \mathrm{~m}$ (the surface elevation at the grounding zone) and $z_{1}=1200 \mathrm{~m}$ (the limit of significant melt-water production). $\theta$ is the surface slope as a function of elevation, which can be obtained from the results given in $\mathrm{E}$ and $\mathrm{H}$ (the area-weighted mean value of $\sin \theta$ is about 0.018 ).

This method neglects the possible refreezing of melt water within the glacier. More importantly, the above estimate of area $(w / \sin \theta \mathrm{d} \zeta)$ is a lower bound on the effective area over which melt occurs because of the many crevasses found on this glacier, especially along the ice-stream margins and the area below about $1000 \mathrm{~m}$. As pointed out by Pfeffer and Bretherton (1987), abundant crevassing can increase the amount of melt-water production by up to $100 \%$ over that expected from a region of area equal to that obtained from a map view at this latitude. As a means of incorporating this large decrease in effective surface albedo, we may increase $Q_{\mathrm{S}}$ given in Equation (3) by a factor of up to 2 .

The integration indicated in Equation (3) with $a(z)$ and $w(z)$ defined as in Equations (1) and (2) (or, equivalently, expressing $w$ and $a$ as functions of the distance inland from the grounding zone, $x$, and the melt-water production as

$$
Q_{\mathrm{S}}=\int_{0}^{L} a(x) w(x) \mathrm{d} x
$$

where $L$ is the distance inland to the $1200 \mathrm{~m}$ elevation contour $(52 \mathrm{~km}))$, yields a total input of surficial melt water 


$$
Q_{\mathrm{S}}=750-1500 \mathrm{~m}^{3} \mathrm{~s}^{-1}
$$

during the period late June to mid-August. (This value may be somewhat higher during the peak ablation period in mid-July.) Several local discharge measurements along the ice-sheet margin indicate that marginal streams can account for approximately $100-150 \mathrm{~m}^{3} / \mathrm{s}$ of this melt water. These marginal streams flow directly off the ice on to the land and the water does not enter the glacier system until a point $4-6 \mathrm{~km}$ below the grounding zone. Thus, approximately $650-1350 \mathrm{~m}^{3} / \mathrm{s}$ of melt water is supplied to the glacier above the grounding zone, with about one-tenth of this entering the large moulin mentioned above.

The question may be asked: does the surficial melt water reach the bed of the glacier at any point above the grounding zone? A related question is: if a subglacial conduit is connected to the sea at its terminal end, will this conduit (which is filled with fresh water) be stable if the glacier bed is $1000 \mathrm{~m}$ or more below sea-level?

One indication that there is a non-zero water flow at the base is the observation of a localized plume of highly turbid water in the relatively non-turbid fjord adjacent to the calving face of the glacier (Fig. 7). The glacier is floating at this point, being approximately $14 \mathrm{~km}$ from the

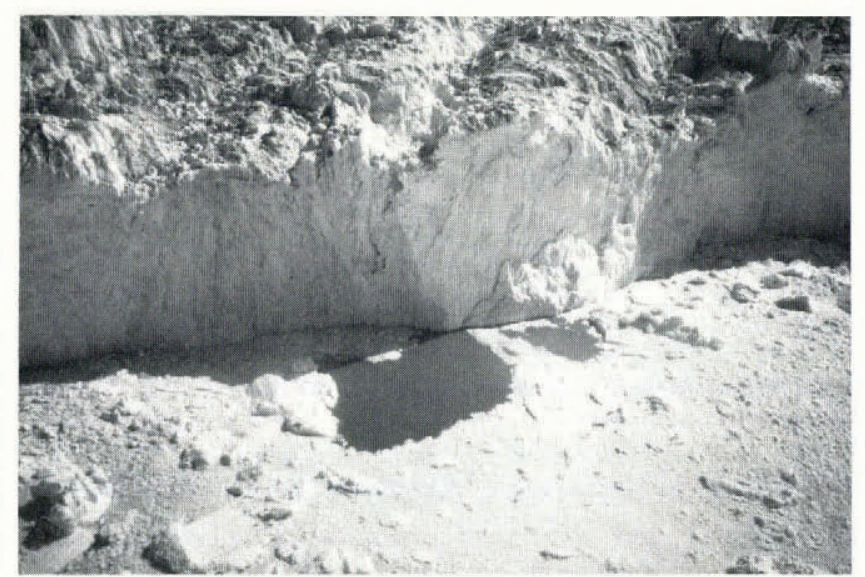

Fig. 7. Photograph of upwelling at calving face of Jakobshavns Isbra. Terminal cliff face is about $80 \mathrm{~m}$ high; the surface of the fjord is covered with brash ice.

grounding zone (Fig. 1), and the ice is about $800 \mathrm{~m}$ thick ( $E$ and $H)$. The upwelling is ephemeral, lasting for several days to weeks and then disappearing until some later date or, at least, the plume fails to displace the brash ice at the zone of upwelling, making it appear to have vanished. The timing of this upwelling is not associated with the periodic drainage of a turbid marginal lake on the northern side of the fjord. The sediment load must come from the base of the glacier above the grounding zone, since there are no other possible sources of turbid water at this location in the fjord. Whether the water transporting the sediment is derived from surface melt or from frictional heating at the bed is not known (however, see below for a discussion of the magnitude of basal melting). The zone of upwelling shown in Figure 7 is approximately $100 \mathrm{~m}$ in diameter, and it is often somewhat larger (200 m diameter). A strong horizontal current has been observed in the upwelling fluid (estimated to be at least $1 \mathrm{~m} \mathrm{~s}^{-1}$ ). This current serves to keep the area of upwelling free of brash ice and icebergs. Given this current and surface area, an estimated flux of $300 \mathrm{~m}^{3} \mathrm{~s}^{-1}$ is possible for the upwelling plume. This flux must be supplied by the hydraulic system of the glacier. The ephemeral nature of the upwelling may be due to a switch from localized water flow beneath or within the floating ice tongue to a more dispersed transport and upwelling. Another possibility is the periodic release of water stored on, within, or beneath the glacier. Such a water reservoir must be extremely large to account for the magnitude of an upwelling event $\left(\sim 2 \times 10^{8} \mathrm{~m}^{3}\right)$. That the upwelling was not observed during the field programs in the winter and early spring of 1985 and 1986 is interesting. Landsat images of the terminus region in July-early Spetember 1982 possibly show a small area of open water near the location of the 1984-86 upwelling, while no such area is apparent in March-early June and late September-October 1982. (The images examined are found in AGRISPINE (1983).)

One other observation indicates that a large amount of water is flowing into the fjord during the ablation season but not at other times of the year. Birnie and Williams (1985) and Williams and Birnie (unpublished) have found that mean iceberg drift rates down the fjord are about $175 \mathrm{~m} / \mathrm{d}$ in late June/early July, $67 \mathrm{~m} / \mathrm{d}$ in September, and nil in March. The influx of fresh water from the glacier may be a major factor in determining these drift rates, particularly since these authors did not find a definite correlation of the drift rates with wind direction and speed - strong easterlies of ten blow during all seasons of the year. Sea ice and brash ice within the fjord during the winter will, of course, hinder iceberg movement. (While the influx of fresh water may be one contributing factor to these variations in drift rates, Birnie and Williams (1985) suggested that the stage of the tide may be a controlling factor for shorter-term fluctuations in drift rates.)

These results indicate that there is a seasonal variation in surficial fresh-water input to the fjord, as is expected, and that there may be a seasonal variation in water which has been in contact with the glacier bed during its travels.

\section{WATER INPUT FROM BASAL MELTING}

In addition to the seasonally dependent surface melt, there will be a supply of water at the bed of the glacier due to frictional (or deformational) heat dissipation. The source of water will not be seasonally dependent, since the velocity is uniform throughout the year. It is of interest to compare this subglacially generated water flux with that expected from surface melting in order to compare the possible contributions of each water source to the processes of basal motion.

A maximal estimate of the amount of water produced at the bed (or within the basal ice layers), $Q_{\mathrm{b}}$, can be obtained from the following simplified model:

Assume that all of the motion of the glacier within that part of the drainage basin where the bed is at the melting point is concentrated at the bed, either in the basal ice layers, or at and within the bed in the form of sliding or deformation of a thin basal debris layer. The bed is assumed to be at the melting point up to a distance of $300 \mathrm{~km}$ inland from the grounding zone, as determined from the temperature profiles along this ice stream calculated by Radok and others (1982, figs 5.18 and 5/3B) and Budd and others $(1982$, map 6/2). There will be a finite layer of temperate ice at the bed for most of this $300 \mathrm{~km}$ length, as indicated by these model results.

The basal velocity, $v$, will be taken to equal the balance velocity as determined by Bindschadler (1984) inland of our $100 \mathrm{~km}$ velocity measurement, and equal to the observed surface velocities ( $E$ and $H$ ) below this point. (This choice conforms to the maximal nature of the estimate of $Q_{\mathrm{b}}$.) This velocity leads to frictional heat dissipation equal to $\tau v$, where $\tau$ is the basal shear stress, which (as a first approximation) is obtained from the thickness and slope listed by Bindschadler (1984). Assuming that conductive losses into the ice column are small (consistent with our maximal estimate and the rapid ice velocity), the total rate of basal melt per unit area per unit time is equal to $(\tau v+q) / h$ where $q$ is the geothermal heat flux (taken to be $0.05 \mathrm{~W} \mathrm{~m}^{-2}$, following Paterson (1981), and $h$ is the latent heat of fusion per unit volume of ice (equal to $\left.3 \times 10^{8} \mathrm{~J} \mathrm{~m}^{-3}\right)$. The geothermal contribution is small in comparison to the frictional dissipation for speeds greater than about $30 \mathrm{~m} \mathrm{a}^{-1}$ along the glacier. The total amount of water produced at the bed of the glacier per unit time, $Q_{\mathrm{b}}$, at a distance $x_{0}$ inland from the grounding zone is given by

$$
Q_{\mathrm{b}}=\frac{1}{h} \frac{\rho_{\mathrm{i}}}{\rho_{\mathrm{w}}} \int^{300}(\tau v+q) w(x) \mathrm{d} x
$$


where $\rho_{\mathrm{i}}, \rho_{\mathrm{w}}$ are the densities of ice and water and $w(x)$ is the width of the basin at a distance $x(\mathrm{~km})$ from the grounding zone.

Performing this integration leads to a maximal estimate for the total influx of subglacially derived melt water at the grounding zone $\left(x_{0}=0\right)$ and at the upper limit of ablation $\left(x_{0}=52 \mathrm{~km}\right)$, assuming all of the subglacial drainage is channeled beneath the ice stream at these locations. This admittedly crude estimation gives

$$
Q_{\mathrm{b}}=64-105 \mathrm{~m}^{3} \mathrm{~s}^{-1}
$$

at the grounding zone and

$$
Q_{\mathrm{b}}=34-50 \mathrm{~m}^{3} \mathrm{~s}^{-1}
$$

at the limit of ablation, $52 \mathrm{~km}$ inland. (The range of values represents the minimum and maximum values for $w(x)$ as obtained from Bindschadler (1984).) At the grounding zone, $Q_{\mathrm{b}}$ amounts to approximately $5 \%$ of the total melt-water discharge and, of course, $100 \%$ of the total discharge at $x_{0}=52 \mathrm{~km}$. The difference between $Q_{\mathrm{b}}$ at the grounding zone and at $x_{0}=52 \mathrm{~km}$ shows the effect of the extreme "sliding" velocities along the lower ice stream. The estimated outflow of turbid water at the terminal upwelling is significantly larger than this subglacially generated discharge, indicating that at least some of the surficial melt water reaches the bed before the grounding zone.

\section{DISCUSSION}

The results described above show that there is a large seasonal influx of surficial melt water to the glacier system and that this water may come into contact with the glacier bed above the grounding zone, but there is no significant variation in surface speed accompanying this influx of water.

If we assume that a large proportion of the motion of this glacier is due to basal sliding or deformation of a basal debris layer, then the lack of any variation in sliding speed with the influx of surficial melt water implies that: (a) the subglacial hydraulic system is dominated by subglacially derived melt water (from frictional/deformational heat dissipation); and/or (b) that surficial melt travels in large subglacial conduits and, for some reason, does not affect the subglacial water pressure (except locally); or (c) that the surficial water travels englacially, and thus does not come into contact with the glacier bed until well down the ice stream, near the grounding zone. In this case, any sliding and/or deformation of a subglacial layer underlying the ablation zone would be relatively unaffected by the seasonally varying surface melt.

The results of the previous section indicate that the first hypothesis (a) is inconsistent with the estimated ratio of supraglacial water sources in the glacier system. The second hypothesis (b) seems unlikely on physical and theoretical grounds - ice-overburden pressures along the ice stream are huge (10-20 MPa) and closure rates in the absence of a large surficial melt-water input to subglacial conduits during 9 months of the year must necessarily be large. The partially or wholly closed conduits would then not be sufficiently large enough to transport the spring/summer melt at a low pressure. If the bed of the glacier was bedrock, then the large seasonal increase in water pressure within the conduits would probably cause pressurization across much of the bed. If the bed of the glacier were composed of a thin, saturated debris layer and the hydraulic regime of this layer was connected to the surface water, then one would expect large seasonal variations in pore-water pressure and, thus, shear strength of the basal layer.

If the glacier is sliding or moving over a deformable bed, then it seems any velocity enhancement by high basal water pressures at the bed must be due to frictionally generated melt and not the surficial water.

On the other hand, Jakobshavns Isbræ may not be sliding for much of its length. If the majority of the glacier's rapid motion were due to internal deformation, then we would expect no seasonal variation in speed. A case in point is Blue Glacier, Washington, as mentioned in the introduction. In this scenario, the surficial melt water need not reach the bed until near the grounding zone (and, there, only a fraction of the total melt needs to come into contact with the bed). Most of the water could travel in englacial conduits, following a hydraulic grade line down to sea-level. Large englacial conduits have been observed by the authors in several icebergs which have rolled to horizontal positions, and these may represent the pathways traveled by a majority of the surficial melt water. Of course, the glacier's motion must be dominated by basal sliding at the grounding zone. The turbid water of the upwelling could be due to the combination of basal melt and a fraction of the surficial melt which reaches the bed near this grounding zone.

The sediment in the turbid water and the shape of the fjord itself indicate that the glacier is an effective erosive agent, and, of course, this must be related to basal processes. However, the basal motion need not be large (at least at the present time).

The possibility of the rapid motion due to internal deformation was discussed by Echelmeyer and Harrison (1989). Further field work (seismic reflection and bore-hole studies) and numerical modeling is presently under way to elucidate further the possible mechanisms of the rapid flow on Jakobshavns Isbræ, including this internal deformation.

\section{ACKNOWLEDGEMENTS}

Many people contributed to the field programs in 1984-86. They include C. Benson, T. Clarke, A. Iken, G. Liston, P. Moore, C. Petersen, J. Power, C. Quintana, D. Roberts, M. Sturm, and C. Tobin. Special thanks go to T. Gaeke and M. Lockwood for sharing the snow cave in the winter, and to pilots of Greenland Air Charter, whose excellent skills made the work possible. PICO provided much-needed help with the logistics and T. Clarke and A. Cosgrove helped with data analysis. $H$. Brecher and $T$. Hughes provided a base map of the region derived from their aerial photography, and I. Whillans graciously lent the satellite geoceivers. This work was supported by U.S. National Science Foundation grant NSP-DPP84-06818.

\section{REFERENCES}

AGRISPINE. 1983. Monitoring iceberg production from West Greenland glaciers using Landsat data: results from the AGRISPINE experiment for Jakobshavns Isbra. Farnborough, England, Royal Aircraft Establishment. National Remote Sensing Centre.

Ambach, W. 1977. Untersuchungen zum Energieumsatz in der Ablationszone des grönländischen Inlandeises. Nachtrag. Medd. Gronl., 187(5).

Andreasen, J.O. 1985. Seasonal velocity variations in a sub-polar glacier in West Greenland. J. Glaciol., 31(108), 319-323.

Battle, W.R.B. 1951. Glacier movement in north-east Greenland, 1949. J. Glaciol., 1(10), 559-563.

Bindschadler, R.A. 1984. Jakobshavns Glacier drainage basin: a balance assessment. J. Geophys. Res., 89(C2), 2066-2072.

Birnie, R.V. and J.M. Williams. 1985. Monitoring iceberg production using Landsat data. Dundee Summer School. Remote Sensing Applications in Civil Engineering. Dundee, 19 August, 1984. Proceedings. (ESA SP-216.)

Boulton, G.S. and R. Vivian. 1973. Underneath the glaciers, Geogr. Mag., 45(4), 311-316.

Budd, W.F., T.H. Jacka, D. Jenssen, U. Radok, and N.W. Young. 1982. Derived physical characteristics of the Greenland ice sheet. Parkville, Victoria, University of Melbourne. Meteorological Department. (Pub. 23.)

Echelmeyer, K. Unpublished. Response of a glacier to a perturbation in thickness: theory and observation. (Ph.D. dissertation, California Institute of Technology, 1983.)

Echelmeyer, K. and W.D. Harrison. 1989. Dynamics of Jakobshavns ice stream, West Greenland. (Abstract.) Ann. Glaciol., 12, 201.

Engelhardt, H.F., W.D. Harrison, and B. Kamb. 1978. Basal sliding and conditions at the glacier bed as revealed by bore-hole photography. J. Glaciol., 20(84), 469-508. 
Harrison, W.D., C.F. Raymond, M. Sturm, K. Echelmeyer, and N.F. Humphrey. 1989. First results from automated motion and stream measurements from Fels and Black Rapids Glaciers, Alaska. (Abstract.) Ann. Glaciol., 12, 203.

Hodge, S.M. 1974. Variations in the sliding of a temperate glacier. J. Glaciol., 13(69), 349-369.

Hooke, R.LeB., J. Brzozowski, and C. Bronge. 1983. Seasonal variations in surface velocity, Storglaciären, Sweden. Geogr. Ann., 65A(3-4), 263-277.

Iken, A. 1974. Velocity fluctuations of an Arctic valley glacier. A study of White Glacier, Axel Heiberg Island, Canadian Arctic Archipelago. Axel Heiberg Isl. Res. Rep. McGill Univ. Glaciol. 5.

Iken, A. 1978. Variations of surface velocities of some Alpine glaciers measured at intervals of a few hours. Comparison with Arctic glaciers. Z. Gletcherkd. Glazialgeol., 13(1/2), 1977, 23-35.

Iken, A. 1981. The effect of the subglacial water pressure on the sliding velocity of a glacier in an idealized numerical model. J. Glaciol., 27(97), 407-421.

Iken, A. and R.A. Bindschadler. 1986. Combined measurements of subglacial water pressure and surface velocity of Findelengletscher, Switzerland. Conclusions about drainage system and sliding mechanism. J. Glaciol., 32(110), 101-119.

Iken, A., A. Flotron, H. Röthlisberger, and W. Haeberli. 1983. The uplift of Unteraargletscher at the beginning of the melt season - a consequence of water storage at the bed? J. Glaciol., 29(101), 28-47.

Kamb, B. and H. Engelhardt. 1987. Waves of accelerated motion in a glacier approaching surge: the mini-surges of
Variegated Glacier, Alaska, U.S.A. J. Glaciol., 33(113), $27-46$.

Lliboutry, L. 1986. General theory of subglacial cavitation and sliding of temperate glaciers. J. Glaciol., 7(49), 21-58.

Paterson, W.S.B. 1961. Movement of Sefstrøms Gletscher, north-east Greenland. J. Glaciol., 3(29), 845-849.

Paterson, W.S.B. 1981. The physics of glaciers. Second edition. Oxford, etc., Pergamon Press.

Pfeffer, W.T. and C.S. Bretherton. 1987. The effect of crevasses on the solar heating of a glacier surface. International Association of Hydrological Sciences Publication 170 (Symposium at Vancouver 1987 - The Physical Basis of Ice Sheet Modelling), 191-205.

Radok, U., R.G. Barry, D. Jenssen, R.A. Keen, G.N. Kiladis, and B. McInnes. 1982. Climatic and physical characteristics of the Greenland ice sheet. Boulder, $\mathrm{CO}$, University of Colorado. Cooperative Institute for Research in Environmental Sciences.

Raymond, C.F. and W.D. Harrison. 1988. Evolution of Variegated Glacier, Alaska, U.S.A., prior to its surge. $J$. Glaciol., 34(117), 154-169.

Thomsen, H.H. 1984. Mass balance measurements at the margin of the inland ice near Jakobshavn, West Greenland. Polar forschung, 54(1), 37-41.

Weertman, J. 1979. The unsolved general glacier sliding problem. J. Glaciol., 23(89), 97-115.

Williams, J.M. and R.V. Birnie. Unpublished. Monitoring calving behavior of glaciers using Landsat data: results for Jakobshavns Isbræ in 1982. Macaulay Institute. Soil Research Report, 1984. 